\title{
Effect of Oxygen on Growth of Azotobacter chroococcum in Batch and Continuous Cultures
}

\author{
By H. DALTON* AND J. R. POSTGATE \\ A.R.C. Unit of Nitrogen Fixation, University of Sussex, \\ Falmer, Brighton, Sussex, BNI $9 Q^{J}$
}

(Accepted for publication 16 August 1968)

SUMMARY

Initiation of growth of nitrogen-fixing Azotobacter species was prevented by efficient aeration but proceeded normally with gentle aeration; addition of $\mathrm{CO}_{2}$ to the air did not relieve inhibition. The ratio of oxygen solution rate to concentration of organisms determined whether growth would be inhibited or not. Populations growing in media containing fixed nitrogen $\left(\mathrm{NH}_{4}^{+}\right)$showed no unusual sensitivity to oxygen though inhibition could be induced at a $P_{\mathrm{O}_{2}}$ value of $0.6 \mathrm{~atm}$. Nitrogen-limited continuous cultures fixed about twice as much $\mathrm{N}_{2} / \mathrm{g}$. carbon source utilized at $0.03 \mathrm{~atm} . \mathrm{O}_{2}$ than at the atmospheric value $(0.2 \mathrm{~atm}$.); even at relatively high cell concentrations growth was inhibited at $0.6 \mathrm{~atm} . \mathrm{O}_{2}$. Carbon- and phosphate-limited continuous cultures showed even more sensitivity to oxygen when fixing nitrogen but none when growing with $\mathrm{NH}_{4}^{+}$; excessive oxygen was lethal to phosphate-limited populations. These observations suggest that two mechanisms exist in the cell to protect the oxygen-sensitive components of nitrogenase from oxygen: augmented respiration to scavenge excess oxygen and a conformational state of nitrogenase that prevents damage by $\mathrm{O}_{2}$.

\section{INTRODUCTION}

High oxygen tensions inhibit or delay the growth of many aerobic or facultatively anaerobic bacteria (Moore \& Williams, I9I I) including Azotobacter species (Meyerhof \& Burk, 1928). However, the mechanisms of such oxygen toxicity remain, to a large extent, obscure. Barron (1955) proposed that harmful effects of oxygen on biochemical material were due mainly to non-specific oxidation of enzyme sulphydryl groups. Chance, Jamieson \& Coles (1965) found that hyperbaric oxygen inhibited energylinked pyridine nucleotide reduction in mitochondria at II to $17 \mathrm{~atm}$. and suggested that oxidation of sulphydryl groups may be important. Certain nutrients may protect in the case of Achromobacter P6, since inhibition at high oxygen tensions depended on the nature of the carbon and energy source and could be reversed by amino acid supplements (Gottlieb, I966).

Oxygen toxicity in Azotobacter at partial pressures of oxygen above a $P_{\mathbf{O}_{2}}$ of $0.6 \mathrm{~atm}$. seems fairly well established (Meyerhof \& Burk, 1928; Tschapek \& Giambiagi, 1955; Schmidt-Lorenz \& Rippel-Baldes, 1957), although Fife (1943) reported that respiratory activity of Azotobacter increased up to a $P_{\mathrm{o}_{2}}$ of $0.8 \mathrm{~atm}$. Meyerhof $\&$ Burk orginally regarded oxygen toxicity as an inhibition of nitrogen fixation, but the phenomenon was later considered to be a general inhibition of growth (Burk, 1930). Parker (1954) argued that, if metabolic hydrogen is involved in the reduction of nitro-

*Present address: Dept. of Biological Sciences, Purdue University, Lafayette, Indiana 47907, U.S.A. 
gen to ammonia, then oxygen should compete for this hydrogen and hence depress fixation. Parker \& Scutt (1960), assuming that spot analyses for $\mathrm{N}$ were measures of nitrogen assimilation rates, obtained kinetic data from growth experiments which showed oxygen to be a competitive inhibitor of nitrogen fixation. Parker (I954) found that nitrogen fixation was more efficient at low oxygen tensions: three times as much nitrogen was fixed per unit glucose consumed at a $P_{\mathrm{O}_{2}}$ of 0.04 atm. than a $P_{\mathrm{O}_{2}}$ of $0.2 \mathrm{~atm}$. Tschapek \& Giambiagi (1955) proposed that the influence of $\boldsymbol{P}_{\mathrm{O}_{2}}$ on nitrogen fixation was intimately linked with respiration but offered no explanation of the inhibition observed. Attempts to shift the inhibitory $P_{\mathrm{O}_{2}}$ to above $0.6 \mathrm{~atm}$., by using different substrates, were unsuccessful and served only to indicate that the mechanism was complex. Schmidt-Lorenz \& Rippel-Baldes (1957) found that increased $P_{\mathrm{O}_{2}}$ only affected nitrogen fixation and not assimilation of bound nitrogen; they came to the conclusion that the unfavourable influence of increasing $P_{\mathrm{O}_{2}}$ on the efficiency of nitrogen fixation was due more to an effect on the $E_{h}$ of the environment than a direct effect on some enzyme system. Khmel, Gabinskaya \& Ierusalimsky (1965) observed that yields of Azotobacter vinelandii fermentations were highest at low aeration rates and that maximum nitrogen fixation occurred at an aeration rate of 18.7 mmole $\mathrm{O}_{2} / 1$. $/ \mathrm{hr}$. Dilworth (1962) found that increasing the $P_{\mathrm{O}_{2}}$ above $0.6 \mathrm{~atm}$. with $A$. vinelandii caused pyruvate accumulation and attributed the $\mathrm{O}_{2}$ inhibition observed to inactivation of the pyruvic oxidase system.

All the results so far have been obtained from studies with batch cultures. Under such conditions the environment is continually changing and reproducibility in the behaviour of populations is sometimes difficult to obtain (Malek, 1966). In this paper we have re-investigated the effect of $P_{\mathrm{O}_{2}}$ on growth and nitrogen fixation in Azotobacter chroococcum by using both batch cultures and continuous cultures.

\section{METHODS}

Organisms and media. Stock cultures of Azotobacter chroococcum NCIB 8003, Azotobacter vinelandii $\mathrm{NCIB} 8660$ and Azotobacter macrocytogenes NCIB 8700 , were maintained on slopes of medium 'mannitol B' (Burk's medium as prescribed by Newton, Wilson \& Burris (1953) with mannitol in place of sucrose) and stored at room temperature. For continuous cultures a modified Burk's medium ('mannitol $\mathrm{B}_{6}$ ') was used which contained (g./1.): mannitol, I0; $\mathrm{K}_{2} \mathrm{HPO}_{4}, 0.64 ; \mathrm{KH}_{2} \mathrm{PO}_{4}, 0.16 ; \mathrm{NaCl}, 0.2 ; \mathrm{MgSO}_{4}$. ${ }_{7} \mathrm{H}_{2} \mathrm{O}, 0 \cdot 2 ; \mathrm{CaCl}_{2}$, o.I ; distilled water plus these trace elements (mg./l.): $\mathrm{FeSO}_{4} \cdot 7 \mathrm{H}_{2} \mathrm{O}$, $2 \cdot 5 ; \mathrm{H}_{3} \mathrm{BO}_{3}, 2 \cdot 9 ; \mathrm{CoSO}_{4} \cdot 7 \mathrm{H}_{2} \mathrm{O}, \mathrm{I} \cdot 2 ; \mathrm{CuSO}_{4} \cdot 5 \mathrm{H}_{2} \mathrm{O}, 0 \cdot \mathrm{I} ; \mathrm{MnCl}_{2} \cdot{ }_{4} \mathrm{H}_{2} \mathrm{O}, 0 \cdot 09 ; \mathrm{Na}_{2} \mathrm{MoO}_{4}$. $2 \mathrm{H}_{2} \mathrm{O}, 2 \cdot 5 ; \mathrm{ZnSO}_{4} \cdot 7 \mathrm{H}_{2} \mathrm{O}, \mathrm{I} \cdot 2$; nitrilotriacetic acid, $100 . \mathrm{NH}_{4} \mathrm{Cl}$ was $200 \mathrm{mg}$./1. when added; final $\mathrm{pH}, 7 \cdot 4 \pm 0 \cdot 2$. Concentrations of mannitol, phosphate and other constituents were altered occasionally as mentioned below.

Twenty-litre batches of medium were autoclaved at $12 \mathrm{I}^{\circ}$ for $45 \mathrm{~min}$., after which time a precipitate was visible. This disappeared after several days at room temperature; the medium was not used until all the precipitate had dissolved.

Viabilities. Slide culture (Postgate, Crumpton \& Hunter, I96I) on mannitol $B_{6}$ medium solidified with agar was used. Annuli were of stainless steel, I.2 mm deep; incubation was for 18 to $24 \mathrm{hr}$ at $25^{\circ}$ and viabilities were reproducible to $\pm 3 \%$.

Apparatus. Continuous culture apparatus with working volumes of approximately $200 \mathrm{ml}$. as described by Baker (1968) was used and maintained at $30^{\circ}$. For batch- 
culture experiments similar vessels without side arms were used. Aeration was effected by magnetic stirring which gave oxygen solution rates of up to $180 \mathrm{mmole} \mathrm{O}_{2} / \mathrm{l}$./hr (see Results). Oxygen solution rates were determined by the sulphite oxidation method (Cooper, Fernstrom \& Miller, 1944).

The oxygen concentration in the culture was continuously measured by using the membrane-covered Clark electrode (Protech Ltd., Rickmansworth). The partial pressures of gases in the gas stream were regulated by gas flowmeters (Rotameter Mfg Co., Croydon), corrected for differences in gas density, the rates of flow being taken as proportional to the partial pressures of gas in the final mixture. At $\boldsymbol{P}_{\mathrm{O}_{2}}$ values below atmospheric, the $P_{\mathrm{N}_{2}}$ was kept constant at $0.8 \mathrm{~atm}$. and argon was introduced into the gas stream to give the required $P_{\mathrm{O}_{2}}$. Above atmospheric $P_{\mathrm{O}_{2}}$, no argon was used and $P_{\mathrm{N}_{2}}$ was equal to $\left(\mathrm{I}-P_{\mathrm{O}_{2}}\right)$. The buffering action of the medium was sufficient to maintain a constant $\mathrm{pH}$ value of 6.8 with nitrogen-fixing populations, so automatic $\mathrm{pH}$ control was necessary only with ammonia-grown bacteria.

Criteria of nutrient limitation. Chemostat cultures were considered limited by a given nutrient when: (I) reduction in concentration of the nutrient by $50 \%$ decreased bacterial concentrations proportionately; (2) a doubling in concentration of all other nutrients in the medium had no effect on bacterial concentration. In the case of $\mathrm{N}_{2}$ limitation, the first criterion was not readily applicable, but a doubling of all medium constituents produced no increase in bacterial concentration. Electrode readings indicated that oxygen was present in excess and so, by elimination, $\mathrm{N}_{2}$ gas was considered to be growth-limiting.

Analytical procedures. To determine organism concentration, duplicate $10 \mathrm{ml}$. samples of culture were filtered through weighed membrane filters (Oxoid Ltd.), the filters washed with an equal volume of distilled water, dried in an oven and weighed. Frequent determinations were made by nephelometric measurements, but these served only as a general indication of cell mass and were not always proportional to it. In continuous cultures a variation in the opacity $\pm 2 \%$ or less over four doubling times was taken as an indication of steady state conditions. Mannitol was estimated by periodate oxidation (Neish, 1950). Cultures were sampled into a few drops of concentrated $\mathrm{H}_{2} \mathrm{SO}_{4}$ (to stop metabolism), centrifuged, and 0.2 to $\mathrm{I} \mathrm{ml}$. of supernatant fluid analysed. Nitrogen was determined by the micro-Kjeldahl technique, followed by colorimetric analysis of ammonia with Nessler's reagent (Meynell \& Meynell, 1965). Respiratory activity was measured by conventional $Q_{\mathrm{o}_{2}}$ estimations in Warburg manometers at $30^{\circ}$. The samples were transferred as rapidly as possible from the culture vessel to the Warburg flask and underwent no centrifuging or washing procedure. For cytochrome spectra, samples were centrifuged and the deposit suspended in medium $B_{6}$ to give a final concentration equivalent to $10 \mathrm{mg} . / \mathrm{ml}$. dry wt bacteria. Two $\mathrm{ml}$. of the concentrated sample were transferred to a diffuse reflectance cell and extinction measured over the range $400-600 \mathrm{~m} \mu$ in a Unicam S.P.700 spectrophotometer. Sodium dithionite was added to obtain reduced spectra.

\section{RESULTS}

Effect of aeration on growth in batch cultures

Batch cultures of Azotobacter chroococcum did not grow after inoculation when subjected to vigorous aeration, but grew when the aeration was initially only slight (Dalton \& Postgate, 1967). Inhibition by high aeration of various aerobic bacteria has 
been generally attributed to lack of $\mathrm{CO}_{2}$, which is necessary for the initiation of growth of many aerobes (Walker, 1932; Gladstone, Fildes \& Richardson, 1935). Such an explanation did not apply to the nitrogen-fixing organisms $A$. chroococcum, $A$. vinelandii and $A$. macrocytogenes, which could be inhibited by efficient aeration even under an atmosphere containing $0.02 \mathrm{~atm} . \mathrm{CO}_{2}$. Azotobacter chroococcum was chosen for further investigation since its behaviour was also being studied in continuous cultures, which were a source of reproducible inocula.

\section{Table I. Aeration and growth of Azotobacter chroococcum}

Batch cultures were inoculated with $A$. chroococcum and stirred at different rates corresponding to the oxygen solution rates quoted for $0.2 \mathrm{~atm} . \mathrm{O}_{2}$. Growth was assessed as visible turbidity; for further details see text.

\begin{tabular}{|c|c|c|c|c|c|c|}
\hline \multirow{2}{*}{$\begin{array}{l}\mathrm{O}_{2} \text { solution rate } \\
\left(\mathrm{mmole} \mathrm{O}_{2} / \mathrm{l} . / \mathrm{hr}\right)\end{array}$} & \multicolumn{3}{|c|}{$\mathbf{N}_{\mathbf{2}}$-grown } & \multicolumn{3}{|c|}{$\mathrm{NH}_{4}^{+}$-grown } \\
\hline & 42 & $42\left(+\mathrm{CO}_{2}\right)$ & $3 \cdot 2$ & 42 & $42\left(+\mathrm{CO}_{2}\right)$ & $3 \cdot 2$ \\
\hline$P_{\mathrm{O}_{2}}$ (atm. & + & + & + & + & + & + \\
\hline 0.2 & - & - & + & + & + & + \\
\hline 0.4 & - & - & + & + & + & + \\
\hline 0.6 & - & - & + & - & - & + \\
\hline
\end{tabular}

Three batch cultures were set up in vessels resembling those used for continuous culture and containing the regular medium with Io g. mannitol/1. Two of these were stirred to give the relatively high aeration rate of $42 \mathrm{mmole} \mathrm{O}_{2} / 1 . / \mathrm{hr}$, one of these had $0.02 \mathrm{~atm} . \mathrm{CO}_{2}$ in the atmosphere passed over the culture, the third was stirred to give the relatively low aeration rate of $3 \mathrm{mmole} \mathrm{O}_{2} / 1 . / \mathrm{hr}$. The cultures were inoculated to equiv. 0.3 $\mu \mathrm{g}$. dry wt Azotobacter chroococcum $/ \mathrm{ml}$. from a nitrogen-limited continuous culture and incubated for up to 4 days at $30^{\circ}$. The results are illustrated in Table I; inhibition by high aeration rates was complete with nitrogen-fixing populations even at atmospheric $\boldsymbol{P}_{\mathbf{O}_{2}}$ values; only at very high $\boldsymbol{P}_{\mathbf{O}_{2}}$ values were $\mathrm{NH}_{4}^{+}$-utilizing strains inhibited. Inhibition depended on inoculum size: at equiv. $0.75 \mu \mathrm{g}$. dry wt organism/ ml. growth was not completely inhibited but merely delayed for about $20 \mathrm{hr}$; at $\mathrm{I} \cdot 5 \mu \mathrm{g} . / \mathrm{ml}$. high aeration induced a lag of about Io $\mathrm{hr}$ as compared with the normal lag of 4 to $5 \mathrm{hr}$. These observations showed that inhibition of growth, apparently due to oxygen toxicity and not to $\mathrm{CO}_{2}$ deprivation, could occur among Azotobacter species in batch cultures. The problem was studied further in continuous flow culture systems in which various parameters influencing growth were more readily controlled.

\section{Effect of aeration on growth and nitrogen fixation in continuous culture}

A steady-state population of Azotobacter chroococcum growing at a dilution rate of $0.2 \mathrm{hr}^{-1}$ and $P_{\mathrm{O}_{2}} 0.2 \mathrm{~atm}$. was established $\left(P_{\mathrm{N}_{2}} 0.8 \mathrm{~atm}\right.$.) in continuous culture. The culture was sampled on three separate days and analysed for nitrogen content, mannitol consumption, dry weight of organism and respiratory activity. The $P_{\mathrm{O}_{2}}$ was then altered and the analyses repeated when the culture was considered to be in a new steady state. Respiratory activity increased with $P_{\mathrm{O}_{2}}$ from $Q_{\mathrm{O}_{2}} 250 \mu \mathrm{l} . \mathrm{mg}$. $/ \mathrm{hr}$ at $0.025 \mathrm{~atm} . \mathrm{O}_{2}$ to a plateau of $Q_{\mathrm{o}_{2}} 950$ between 0.2 and $0.5 \mathrm{~atm} . \mathrm{O}_{2}$.

Figures for the steady state yields of organism and of nitrogen fixed under various partial pressures of oxygen are plotted in Fig. I. The yield of organisms showed a 
plateau about the range of normal air and decreased at very low or high $P_{\mathbf{O}_{2}}$ values. In contrast, the nitrogen fixed per $\mathrm{g}$. mannitol increased at low $P_{\mathrm{O}_{2}}$ values to uncommonly high values. The efficiency of nitrogen fixation at the ordinary atmospheric $P_{\mathrm{O}_{2}}$ of 0.2 ( $37 \mathrm{mg}$. N/g. mannitol) is higher than most values recorded in the literature; we attribute this fact to the use of continuous culture, because the criteria given in Methods, together with other evidence, indicated that the growth-limiting substrate in these conditions was nitrogen gas, and cultures in such conditions would select for bacterial variants of high nitrogen-fixing activity.

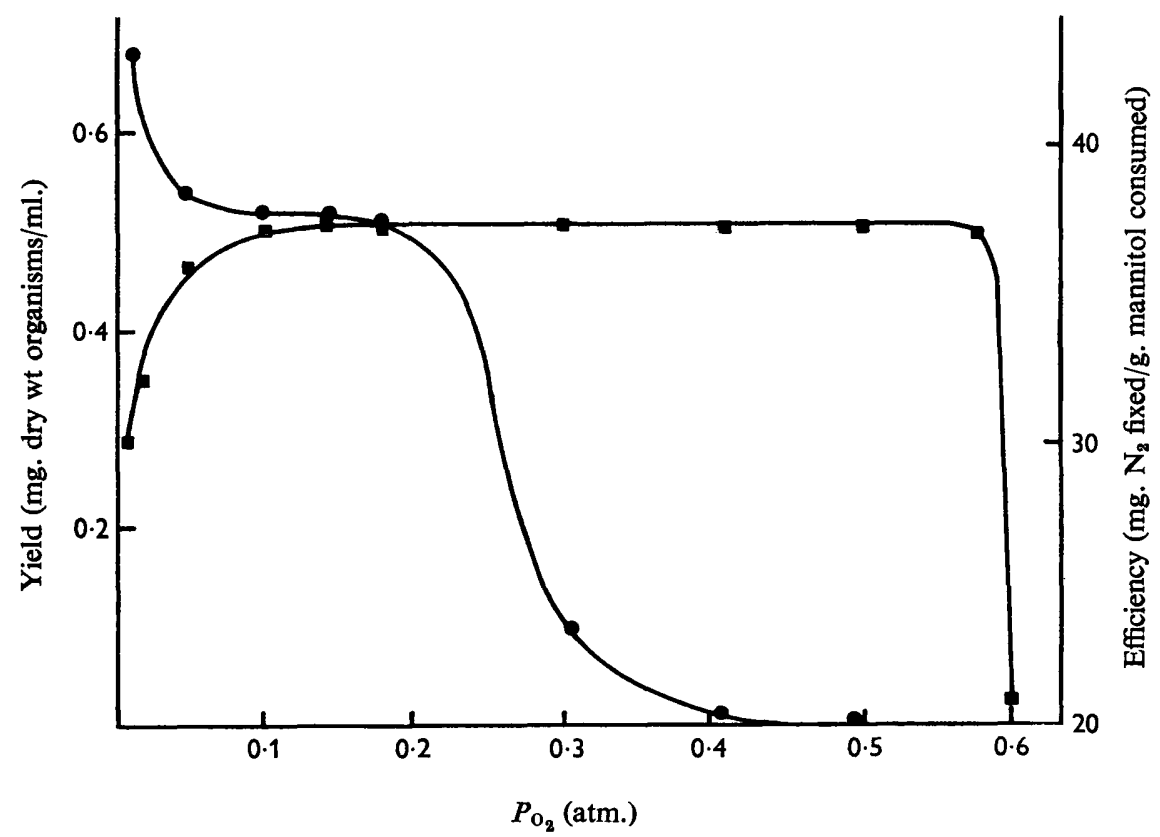

Fig. I. Concentrations of bacteria and efficiencies of nitrogen fixation in continuous cultures of Azotobacter chroococcum under various partial pressures of oxygen at $D=0.2 \mathrm{hr}^{-1}$. $\boldsymbol{Q}$, efficiency; $\mathbf{\square}$, organism concentration.

These cultures were not particularly sensitive to high oxygen tensions until $P_{\mathrm{O}_{2}}$ values in excess of $0.6 \mathrm{~atm}$. were reached; this figure is comparable to figures given by earlier workers and discussed in the introduction. Steady-state populations were then established at $P_{\mathrm{O}_{2}}=0.2 \mathrm{~atm}$. and the mannitol concentration decreased until this substrate became formally the growth-limiting substrate and determined the steadystate yield of organisms. Such populations proved difficult to establish and unstable when established because they showed hypersensitivity to oxygen even at normal atmospheric $P_{\mathrm{O}_{2}}$ : at a dilution rate of $0.14 \mathrm{hr}^{-1}$ a mannitol-limited nitrogen-fixing population (grown with mannitol $0.15 \mathrm{~g} . / \mathrm{l}$. medium) showed $30 \%$ inhibition of growth (yield declined from $0.35 \mathrm{mg} . / \mathrm{ml}$. to $0.24 \mathrm{mg} . / \mathrm{ml}$.) in $2 \mathrm{hr}$ when the oxygen supply to the organism was increased, either by increasing the stirring rate from 680 to I $100 \mathrm{rev} . / \mathrm{min}$. or the $P_{\mathrm{O}_{2}}$ from 0.2 to $0.5 \mathrm{~atm}$. (the stirring rates quoted approximate to $\mathrm{O}_{2}$ transfer rates of $16.0 \mathrm{mmole} \mathrm{O}_{2} / \mathrm{l}$./hr and $70 \mathrm{mmole} \mathrm{O}_{2} / \mathrm{l}$./hr respectively). The population recovered when the oxygen supply was brought back to normal. 
Carbon-limited populations growing with fixed nitrogen $\left(\mathrm{I} \cdot 5 \mathrm{~g} . / 1 . \mathrm{NH}_{4} \mathrm{Cl}\right.$ under $\mathrm{A}+\mathrm{O}_{2}$ mixtures) did not show such sensitivity to aeration.

Tests of the carbon-limited nitrogen-fixing population by using oxygen electrodes showed that an ambient oxygen concentration in the actual culture of Io $\mu \mathrm{M}$ (equivalent to $0.0 \mathrm{I}$ atm. $\mathrm{O}_{2}$ at saturation) was the highest tolerated. When the dissolved oxygen concentration exceeded this value, growth was inhibited; when it fell much below this value, oxygen tended to become the growth-limiting substrate. Nitrogenlimited populations required an ambient $\mathrm{O}_{2}$ of about $20 \mu \mathrm{M}$ for maximum growth and were more tolerant of increased $\mathrm{O}_{2}$ supply than $\mathrm{C}$-limited populations. However,

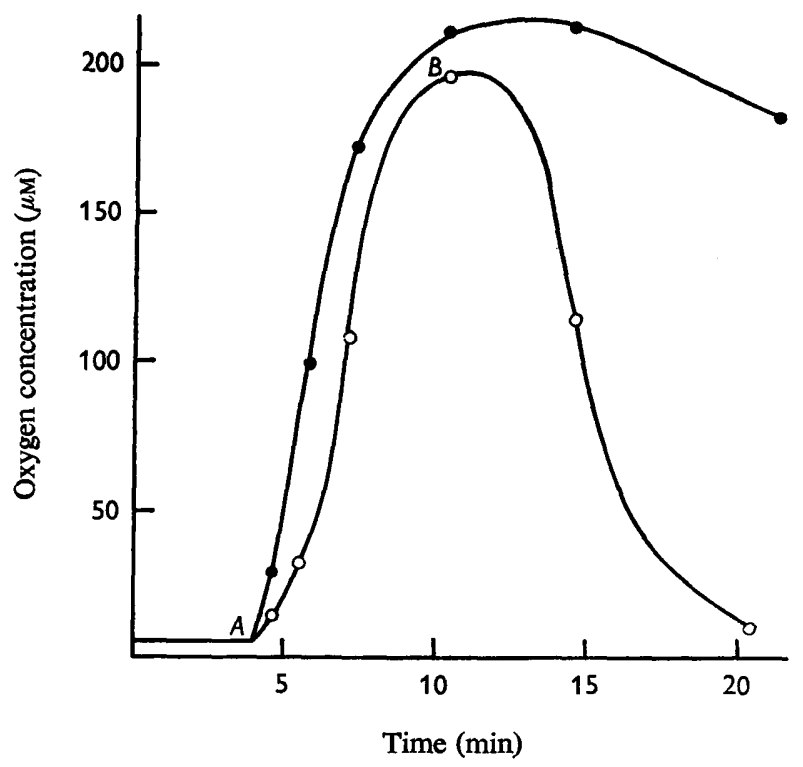

Fig. 2. Effect of increasing $P_{\mathrm{O}_{2}}$ on dissolved $\mathrm{O}_{2}$ in a steady-state culture of Azotobacter chroococcum at $D=0.15 \mathrm{hr}^{-1}$.,$- P_{\mathrm{O}_{2}}$ increased from 0.24 to 0.39 atm. at $A$. $O-O$, $P_{\mathrm{O}_{2}}$ increased from 0.24 to 0.39 atm. at $A$, returned to 0.24 atm. at $B$.

inhibition of growth did occur when the dissolved $\mathrm{O}_{2}$ concentration was in excess of $30 \mu \mathrm{M}$. Oxygen inhibition was reflected in dramatic changes in the dissolved oxygen concentration when aeration conditions were altered. Figure 2 illustrates the effect of increa sing the $P_{\mathrm{O}_{2}}$ over a nitrogen-limited culture in a steady state at $D=0.15 \mathrm{hr}^{-1}$.

The hypersensitivity of carbon-limited populations to oxygen inhibition suggested that nitrogen-limited populations, if grown slowly so as to allow maximum use of available carbon, might show comparable hypersensitivity. Such a population, grown slowly at $0.05 \mathrm{hr}^{-1}$ but with mannitol (I0 g./1.), which would normally be sufficient, showed inhibition by high aeration (I90 mmole $\mathrm{O}_{2} / \mathrm{l} . / \mathrm{hr}$ ) under the normal $P_{\mathrm{O}_{2}}$ of $0.2 \mathrm{~atm}$.; it did not show such inhibition at faster growth rates. The question whether the population was shifted from a formal $\mathrm{N}_{2}$ limitation to a formal mannitol limitation by an increase in the aeration rate will be considered in the Discussion.

Phosphate-limited populations were also hypersensitive to oxygen. A phosphatelimited, nitrogen-fixing population ( $1 \cdot 78 \mathrm{mg} . / \mathrm{P} / \mathrm{l}$.), growing at a dilution rate of $0.115 \mathrm{hr}^{-1}$ with an oxygen solution rate of 15 mmole $\mathrm{O}_{2} / 1 . / \mathrm{hr}\left(P_{\mathrm{O}_{2}}=0.2 \mathrm{~atm}\right.$. $)$, gave 
a yield of $0.95 \mathrm{mg}$. dry wt organism $/ \mathrm{ml}$. Increasing the oxygen solution rate to $70 \mathrm{mmole} \mathrm{O}_{2} / \mathrm{l} / \mathrm{hr}$, by increasing the stirring rate, decreased the yield to $0.35 \mathrm{mg}$. $/ \mathrm{ml}$. over a $14 \mathrm{hr}$ period. Similarly, an increase in $P_{\mathrm{O}_{2}}$ from 0.08 to $0.20 \mathrm{~atm}$. at the higher stirring rate (I050 rev./min.) caused a decrease in yield from $0.7 \mathrm{mg} . / \mathrm{ml}$. to $0.25 \mathrm{mg} / \mathrm{ml}$. over a $24 \mathrm{hr}$ period at a dilution rate of $0.14 \mathrm{hr}^{-1}$. As with mannitol-limited populations, the effect was reversible; however, the culture could be sterilized completely when high aeration was continued for 3 days at a dilution rate of $0.05 \mathrm{hr}^{-1}$. Populations using $\mathrm{NH}_{4}^{+}$instead of fixing atmospheric $\mathrm{N}_{2}$ again showed no such oxygen sensitivity.

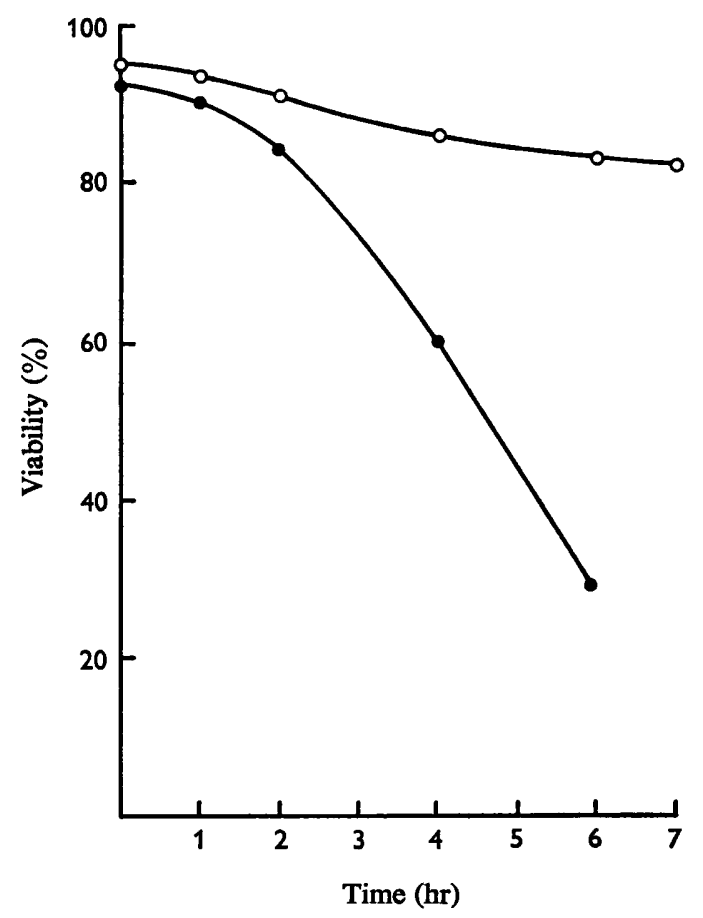

Fig. 3. Survival of over-aerated populations of Azotobacter chroococcum from continuous cultures. Steady-state populations of $A$. chroococcum were established at $D=0.2 \mathrm{hr}^{-1}$ in mannitol-limited (1.5 g. mannitol/1.) and phosphate-limited ( $0.05 \mathrm{~g}$. $\mathrm{K}_{\mathbf{2}} \mathrm{HPO}_{\mathbf{4}} / \mathrm{l}$.) conditions and gave 0.4 and $0.45 \mathrm{mg}$. dry wt organisms $/ \mathrm{ml}$. respectively. At zero time, flow of medium

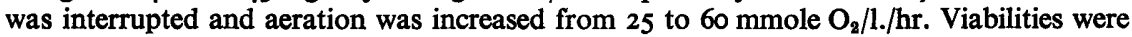
then assessed by slide culture (see text). $O$, Carbon-limited population; $O$, phosphatelimited population.

\section{Lethality of oxygen}

The lethality of oxygen to sensitive populations was studied by obtaining steadystate carbon-limited and phosphate-limited populations of similar population densities to avoid population effects on survival (Postgate \& Hunter, 1963). Then, simultaneously, the flow of medium was stopped and the aeration rate increased just over twofold; the viability was then monitored by slide culture during several hours. This procedure gave a measure of the lethality of oxygen to the populations, uncomplicated by 'cryptic' growth which occurred when the cultures were left running. Figure 3 shows that oxygen was lethal to $70 \%$ of a phosphate-limited population over $6 \mathrm{hr}$; 
it was much less lethal to the carbon-limited population, though the decline in viability recorded is significant. Nitrogen-limited populations showed no decline in viability in comparable conditions.

\section{DISCUSSION}

Increased efficiency of nitrogen fixation at low $\boldsymbol{P}_{\mathrm{O}_{2}}$ values observed with batch cultures of Azotobacter by Parker (1954) was attributed to competition between oxygen and nitrogen for electrons by Parker \& Scutt (1960), nitrogen fixation being regarded as a form of respiration. Our findings confirm the observations of Parker and his colleague and extend them to organisms in continuous culture; the complete inhibition of growth by high levels of oxygenation which we have observed presumably reflects an extreme state of oxygen competition, since it is specific to nitrogen-fixing populations. Inhibition was most marked with carbon-limited and phosphate-limited populations when these were fixing nitrogen and in these circumstances oxygen could be lethal to the organisms. We present an interpretation of the effects of oxygen on the physiology of Azotobacter on the basis of these findings and present knowledge of the behaviour of cell-free nitrogenase preparations.

Nitrogen-fixing systems have been extracted from Azotobacter vinelandii (Bulen, Burns \& LeComte, 1965) and A. chroococcum (Kelly, I966) in particulate forms which, unlike the soluble extracts of Clostridium pasteurianum (Carnahan, Mortenson, Mower \& Castle, I960), are reasonably stable in air. They can be further resolved into two soluble components, both of which are necessary for nitrogen fixation but which have become extremely sensitive to oxygen and readily damaged unless handled in anaerobic conditions (Bulen \& LeComte, 1966; Kelly, Klucas \& Burris, 1967). Nitrogen-fixing cell-free extracts of blue-green algae also appear to be oxygensensitive (Fay \& Cox, 1967). These observations provide evidence that, even in aerobic bacteria, the components of nitrogenase are intrinsically sensitive to oxygen. The living organism, since it grows in air, must possess a mechanism for protecting the nitrogen-fixing site from oxygen. The oxygen-tolerance of the particulate preparations suggests that some steric arrangement of the components makes for oxygen tolerance and, in principle, this 'conformational protection', as we shall term it, could operate in two ways. Either the oxygen-sensitive sites could be inaccessible to oxygen, or they could be stabilized by conformational features of the nitrogenase complex so that, though accessible to oxygen, they would be undamaged by it.

Our findings lead us to assume that a second protective mechanism also operates in the living organism: that respiration is used to scavenge oxygen from the neighbourhood of the nitrogen-fixing site. Such a mechanism was proposed by Phillips \& Johnson (196I) as a result of their observations that Azotobacter vinelandii, given excess oxygen, consumed sugar at rates greater than those necessary to supply the energy requirement. They suggested that respiration functioned as an 'oxygen-wasting system' which maintained a low $E_{h}$ value within the cell, presumed to be necessary for nitrogen fixation. Evidence pointing to respiration as a protective process is provided by numerous other publications, including Meyerhof \& Burk (I928), Burk (I930), Parker (I954), Schmidt-Lorenz \& Rippel-Baldes (1957), Parker \& Scutt (I960), Dilworth \& Parker (196I) and Khmel et al. (1965), even though their findings were not always interpreted as implying a protection process. Our reasons for regarding respiration as protective to the nitrogenase complex are the following. (I) Respiration 
in nitrogen-limited nitrogen-fixing cultures is adjusted to balance oxygen supply and leaves nitrogen fixation largely unaffected. In conditions of high aeration or high $\boldsymbol{P}_{\mathbf{O}_{\mathbf{g}}}$ nitrogen fixation became remarkably inefficient in terms of carbon substrate consumed; in near anaerobic conditions it became highly efficient, though the growth yield of the population was then not impressive. (2) In carbon-limited nitrogen-fixing cultures, which could not adjust their respiration to match oxygen tension, extreme oxygen sensitivity was observed. (3) The inhibitory $P_{\mathrm{O}_{2}}$ in the gas phase varied according to the population density but the maximum tolerated molarity of oxygen in the culture medium remained much the same, indicating that a balance between solution and consumption of oxygen was being actively maintained. (4) Hypersensitivity to oxygen was not shown by populations that were not fixing nitrogen.

Our direct measurements of $Q_{\mathrm{o}_{2}}$ values showed a trend in the direction of high $Q_{\mathrm{o}_{2}}$ corresponding to high $\boldsymbol{P}_{\mathrm{O}_{2}}$, as we should expect on this hypothesis, but we do not attach great significance to the actual $Q_{\mathrm{o}_{\mathrm{z}}}$ values because of the rapid alteration in $Q_{\mathrm{O}_{\mathbf{z}}}$ that follows handling of bacterial populations. Nevertheless, it seems logical to accept that the high $Q_{\mathrm{O}_{3}}$ values for which the Azotobacteriaceae are famous (4000 to $5000 \mu \mathrm{l}$. $\mathrm{O}_{2} / \mathrm{mg}$. dry wt $/ \mathrm{hr}$; Williams \& Wilson, 1954) represent a mechanism for excluding oxygen from parts of the cell.

The existence of some kind of conformational protection, supplemented in the actively growing and fixing organism by respiratory protection, accounts for the behaviour of nitrogen-limited and putatively carbon-limited populations. It raises the question whether the so-called carbon-limited populations obtained here were truly carbon-limited. The yield certainly depended on the carbon concentration in the inflowing medium, but it was likely that the rates of carbon and nitrogen assimilation were finely balanced such that a small excess of carbon was available for the respiratory protection mechanism. The concept of limitation by single nutrients in chemostats thus becomes rather involved in a circumstance in which oxygen concentration is critical and access of nitrogen to nitrogenase is limited by some intracellular mechanism.

Ammonia-grown organisms showed no abnormal sensitivity to oxygen; the failure of such inocula to grow at $P_{\mathrm{O}_{2}}$ values of 0.6 is probably analogous to the sensitivity to hyperbaric oxygen shown by other bacteria. Many microbes respond to plentiful availability of oxygen by bringing in non-cytochrome respiratory pathways (Lenhoff, Nicholas \& Kaplan, 1956; Rosenberger \& Kogut, 1958). Reflectance spectra (Giovanelli, 1957), as adapted to Azotobacter by Moss \& Tchan (1958), were determined on bacteria grown with high and low aeration. No impressive change in the heights of the cytochrome peaks between 400 and $650 \mathrm{~m} \mu$ appeared, suggesting that a noncytochrome pathway was not used by Azotobacter chroococcum. Moreover, the sensitivity of phosphate-limited populations to oxygen suggests that the respiratory protective mechanism operates through the cytochrome pathway, since otherwise there is no reason for such cells to be sensitive. The ATP:ADP ratio is known to exert a controlling effect on mitochondrial respiration (Klingenberg \& Schollmeyer, 1960), and there are indications that phosphate compounds and nucleotides exert some respiratory control in bacteria (Ishikawa \& Lehninger, 1962; Revsin \& Brodie, 1967); ADP will stimulate and ATP inhibit the respiration of $A$. chroococcum (M. G. Yates, personal communication). If, in the phosphate-limited population, respiration is suddenly augmented to compensate for an increase in oxygen concentration, then ADP would be converted to ATP. If the control mechanism were analogous to that in 
mitochondria, the ATP:ADP ratio would thus be shifted in favour of decreased respiration and, because the respiratory protective mechanism had been thwarted, the nitrogenase would no longer function properly and growth would cease. In these circumstances permanent damage to the nitrogenase might ensue and $\mathrm{O}_{2}$ might become lethal; the exceptional lethality of oxygen to phosphate-limited populations might well be a reflexion of this condition.

\section{REFERENCES}

BAKER, K. (1968). Low cost continuous culture apparatus. Lab. Practice 17, 817.

BARRON, E. S. G. (1955). Oxidation of some oxidation-reduction systems by oxygen at high pressures. Archs. Biochem. Biophys. 59, 502.

Bulen, W. A. \& LeComte, J. R. (I966). The nitrogenase system from Azotobacter: two-enzyme requirement for $\mathrm{N}_{2}$ reduction, ATP-dependent $\mathrm{H}_{2}$ evolution, and ATP hydrolysis. Proc. natn. Acad. Sci. U.S.A. 56, 979.

Bulen, W. A., BuRns, R. C. \& LeComte, J. R. (1965). Nitrogen fixation: hydrosulfite as electron donor with cell-free preparations of Azotobacter vinelandii and Rhodospirillum rubrum. Proc. natn. Acad. Sci. U.S.A. 53, 532.

BURK, D. (I930). The influence of oxygen gas upon the organic catalysis of nitrogen fixation by Azotobacter. J. phys. Chem. 34, I 195.

Carnahan, J. E., Mortenson, L. E., Mower, H. F. \& Castle, J. E. (1960). Nitrogen fixation in cellfree extracts of Clostridium pasteurianum. Biochim. biophys. Acta 44, 520.

Chance, B., Jamieson, D. \& Coles, H. (1965). Energy-linked pyridine nucleotide reduction: inhibitory effects of hyperbaric oxygen in vitro and in vivo. Nature, Lond. 206, 257.

Cooper, C. M., Fernstrom, G. A. \& Miller, S. A. (1944). Performance of agitated gas-liquid contactors. Ind. Engng Chem. 36, 504.

Dalton, H. \& Postgate, J. R. (1967). Inhibition of growth of Azotobacter by oxygen. J. gen. Microbiol. 48, v.

DILWORTH, M. J. (1962). Oxygen inhibition in Azotobacter vinelandii pyruvate oxidation. Biochim. biophys. Acta 56, 127.

Dilworth, M. J. \& PARKer, C. A. (196I). Oxygen inhibition of respiration in Azotobacter. Nature, Lond. I9I, 520.

FAY, P. \& Cox, R. M. (1967). Oxygen inhibition of nitrogen fixation in cell-free preparations of bluegreen algae. Biochim. biophys. Acta r43, 562.

FIFE, J. M. (1943). The effect of different oxygen concentrations on the rate of respiration of Azotobacter in relation to the energy involved in nitrogen fixation and assimilation. J. agric. Res. 66, 421 .

Giovanelli, R. G. (1957). The application of diffuse reflection spectrophotometry to chemical analysis. Aust. J. exp. Biol. Med. 35, 143.

Gladstone, G. P., Fildes, P. \& Richardson, G. M. (1935). Carbon dioxide as an essential factor in the growth of bacteria. Br. J. exp. Path. 16, 335 .

GoTrLIEB, S. F. (1966). Bacterial nutritional approach to mechanisms of oxygen toxicity. J. Bact. 92, IO2I.

ISHIKAWA, S. \& LEHNINGER, A. L. (1962). Reconstitution of oxidative phosphorylation in preparations from Micrococcus lysodeikticus. J. biol. Chem. 237, $240 \mathrm{I}$.

KeLlY, M. (1966). Studies on nitrogen fixation by cell-free extracts of Azotobacter chroococcum. Abs. IX int. Congr. Microbiol., Moscow, p. 277 (C2/20).

Kelly, M., KLUCAS, R. V. \& BuRRIS, R. H. (1967). Fractionation and storage of nitrogenase from Azotobacter vinelandii. Biochem. J. ro5, $3 \mathrm{C}$.

Khmel, I. A., Gabinskaya, K. N. \& Ierusalimsky, N. D. (1965). Growth and nitrogen fixation of Azotobacter vinelandii under different aeration conditions. Mikrobiologiya 34, 689.

KLINGenberg, M. \& SCHOllmeYer, P. (1960). Zur Reversibilität der oxydativen Phosphorylierung Biochem. Z. 333, 335 .

Lenhoff, H. M., Nicholas, D. J. D. \& KaPlaN, N. O. (1956). Effects of oxygen, iron and molybdenum on routes of electron transfer in Pseudomonas fluorescens. J. biol. Chem. 220, 983. 
MALEK, I. (1966). In Theoretical and Methodological Basis of Continuous Culture of Microorganisms. Ed. by I. Malek and Z. Fencl, p. I I. London: Academic Press.

MEYERHOF, O. \& BURK, D. (1928). Über die Fixation des Luftstickstoffs durch Azotobakter. Z. phys. Chem. (A) 139, I 17.

Meynell, G. G. \& Meynell, E. (1965). Theory and Practice in Experimental Bacteriology. Cambridge University Press.

MoORE, B. \& WiLliams, R. S. (I9II). The growth of various species of bacteria and other microorganisms in atmospheres enriched with oxygen. Biochem. J. 5, I8I.

Moss, F. J. \& TCHAN, Y. T. (1958). Studies of N-fixing bacteria. VII. Cytochromes of Azotobacteriaceae. Proc. Linn. Soc. N.S.W. 83, I6I.

NeisH, A. C. (1950). Analytical Methods for Bacterial Fermentations. Nat. Res. Council, Canada, Rep. 46-8-3, Saskatoon.

NewTon, J. W., WILSON, P. W. \& BURRIS, R. H. (1953). Direct demonstration of ammonia as an intermediate in nitrogen fixation by Azotobacter. J. biol. Chem. 204, 445.

Parker, C. A. (1954). Effect of oxygen on the fixation of nitrogen by Azotobacter. Nature, Lond. r73, 780.

Parker, C. A. \& Scutt, P. B. (1960). The effect of oxygen on nitrogen fixation by Azotobacter. Biochim. biophys. Acta 38, 230.

Phillips, D. H. \& Johnson, M. J. (196I). Measurement of dissolved oxygen in fermentations. J. biochem. microbiol. Technol. Engng 3, 277.

Postgate, J. R. \& Hunter, J. R. (1963). The survival of starved bacteria. J. appl. Bact. 26, 295.

Postgate, J. R., CRUMpton, J. E. \& HunteR, J. R. (196I). The measurement of bacterial viabilities by slide culture. J. gen. Microbiol. 24, I5.

Revsin, B. \& BRODIE, A. F. (1967). An effect of inorganic phosphate and AMP at the third phosphorylative site of the respiratory chain of Mycobacterium phlei. Biochem. biophys. Res. Commun. 28, 635 .

ROSENBERGER, R. F. \& KoGUT, M. (1958). The influence of growth rate and aeration on the respiratory and cytochrome system of a fluorescent pseudomonad grown in continuous culture. J. gen. Microbiol. 19, 228.

SCHMIDT-LORENZ, W. \& RIPPEL-BALDEs, A. (1957). Wirkung des Sauerstoff-Partialdrucks auf Wachstum und Stickstoff bindung von Azotobacter chroococcum Beij. Arch. Mikrobiol. 28, 45.

TsCHAPEK, M. \& GiambiagI, N. (1955). Nitrogen fixation of Azotobacter in soil-its inhibition by oxygen. Arch. Mikrobiol. 21, 376.

WALKER, H. H. (1932). Carbon dioxide as a factor affecting lag in bacterial growth. Science, N.Y. 76, 602.

Williams, A. M. \& Wilson, P. W. (1954). Adaptation of Azotobacter cells to tricarboxylic acid substrates. J. Bact. 67, 353. 